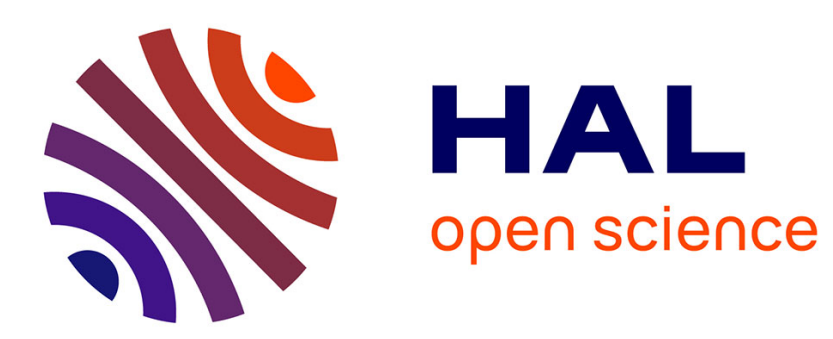

\title{
On the occurrence of gold mineralization in the Pala Neoproterozoic formations, South-Western Chad
}

Rigobert Tchameni, Jean-Claude Doumnang, Marambaye Deudibaye, Yannick Branquet

\section{- To cite this version:}

Rigobert Tchameni, Jean-Claude Doumnang, Marambaye Deudibaye, Yannick Branquet. On the occurrence of gold mineralization in the Pala Neoproterozoic formations, South-Western Chad. Journal of African Earth Sciences, 2013, 84, pp.36-46. 10.1016/j.jafrearsci.2013.03.002 . insu-00809472

\section{HAL Id: insu-00809472}

\section{https://hal-insu.archives-ouvertes.fr/insu-00809472}

Submitted on 30 Apr 2013

HAL is a multi-disciplinary open access archive for the deposit and dissemination of scientific research documents, whether they are published or not. The documents may come from teaching and research institutions in France or abroad, or from public or private research centers.
L'archive ouverte pluridisciplinaire HAL, est destinée au dépôt et à la diffusion de documents scientifiques de niveau recherche, publiés ou non, émanant des établissements d'enseignement et de recherche français ou étrangers, des laboratoires publics ou privés. 


\title{
On the occurrence of gold mineralization in the Pala Neoproterozoic formations, South-Western Chad
}

Tchameni Rigobert ${ }^{1,}$ a Doumnang Jean Claude ${ }^{2}$, Deudibaye Marambaye ${ }^{1,3}$ and Branquet Yannick $^{4}$

1) Département des Sciences de la Terre, Université de Ngaoundéré, B.P. 454 Ngaoundéré, Cameroun

${ }^{2)}$ Département de Géologie, Université de N'Djamena, B.P. 1027 N'Djamena, Tchad

${ }^{3)}$ Ministère de Mines de l'énergie et du Pétrole - N'djamena, Tchad

4) OSUC - Observatoire des Sciences de l'Univers en Région Centre, Campus Géosciences Université - CNRS , 1a Rue de la Férolerie, 45071 Orléans cedex 2, France

${ }^{\text {a) Corresponding author (e-mail: rigotchameni@yahoo.fr) }}$

\begin{abstract}
The Pala region, in southwestern Chad, belongs to the northern part of the Central African Pan-African Fold Belt. It is made up of greenschist-facies schists and is characterized by bimodal, mainly mafic, magmatism. This schist unit named Goueigoudoum Series is intruded by pre- to post-tectonic plutonic rocks dated between 737 and $570 \mathrm{Ma}$ and dykes of quartz. Gold is mined artisanally from alluvial deposits and primary chalcopyrite-pyrite-bearing quartz veins, brecciated and silicified zones and shear zones. The majority of the mineralized shear zones and some quartz veins generally trend N-S to NNE-SSW or NW-SE and are interpreted as extensional shear fractures related to regional NE-SW-trending sinistral strikeslip shear zones. The geological context of the Pala region clearly indicates hydrothermal fluids formed along active continental margins during collisional orogenesis, and subsequent associated fluid migration typically occurred during strike-slip events. Although the origin of fluids may be varied (magmatic, metamorphic or meteoric fluids, Proterozoic seawater, or sedimentary basin formation waters), the distribution of the mineralizations along the granitoid intrusions suggests that magmatism played a major role in the dynamics of the mineralizing fluids
\end{abstract}

Key words: Pan-African Fold Belt; SW Chad; Gold mineralization; Au-bearing quartz veins; Shear zone; Hydrothermalism. 


\section{1. - Introduction}

Orogenic gold deposits have formed over more than 3 billion years of Earth's history, episodically during the Middle Archean to younger Precambrian, and continuously throughout the Phanerozoic (Goldfarb et al., 2001). This class of gold deposit is characteristically associated with deformed and metamorphosed mid-crustal blocks, particularly in spatial association with major crustal structures (Kuleshevicha and Furman, 2009). A consistent spatial and temporal association with granitoids of a variety of compositions indicates that melts and fluids were both inherent products of thermal events during orogenesis (Bjerkgard et al., 2009). Including allochthonous alluvial auriferous placers, which are commonly intimately associated with noble metal classified as platy gold, the production and resources from economic Phanerozoic orogenic-gold deposits are estimated at just over one billion ounces of gold (Goldfarb et al., 2001; Nesterenko and Kolpakov, 2010). Excluding the Witwatersrand ores, known Precambrian gold resources are about half of this amount (Goldfarb et al., 2001). The Pala Gold region, south-western Chad, hosted in the Precambrian Mayo Kebbi formations (Kasser, 1995; Penaye et al., 2006), contains several occrurences of orogenic-gold deposits.

The region of the Pala has long been known for its gold occurrences (Chaussier, 1970; Djekoundam, 1995; Kasser 1995; Kusnir and Moutaye, 1997; Mahamat Boka, 2010; Deurdibaye Marambaye, 2011; Moussa Isseini, 2011; Moussa Isseini et al., 2012). This is testified by the numerous vestiges of artisanal workings which can be found in almost each village of the area (e.g. Gamboké, Mayo Ndala, Massonebaré, Gouyegoudoum, M'bidou and Bamdi). The first important gold prospection projects in this region dates back from 1987 to 1991 and were led by BRGM and PNUD (CHD/87/010 and CHD/91/0007 projects, Schneider, 1989; JIPROMIT, 1995). Continued exploitation has been made by KIGAM Korean Society with a gold grade of ca 33g/t at Gamboké (Soo-Young and Jung, 2001).

This paper aims to characterize gold occurrences of the Pala region, including their geological setting. The data provide a framework for the large-scale geological and tectonic context of the Pala gold, and identify a structure favourable to gold mineralization in South West Chad. 


\section{2.- Geological setting}

The Mayo Kebbi in southwestern Chad is located between the Pan-African reworked Archean and Paleoproterozoic Adamaoua-Yade domain to the east and the Western domain of the Central

African Orogenic Belt that recorded both Paleoproterozoic and Neoproterozoic juvenile accretion to the west. From recent investigations, it has been argued that the Mayo Kebbi massif was formed during the Neoproterozoic in response to the closure of an ocean involving juvenile accretion related to an active margin tectonic setting (Pouclet et al., 2006; Penaye et al., 2006; Moussa Isseini, 2011).

The Mayo Kebbi belongs to the northern part of the Central African Pan-African Fold Belt (CAPFB, Bessoles and Trompette 1980; Toteu et al., 2004). The Pan-African belt in central Africa (Cameroon, Chad, Central African Republic) north of the Congo craton (Fig. 1a), also known as Oubanguides or North Equatorial fold belt (Poidevin 1983; Nzenti et al. 1988), is the southernmost branch of the Pan-Africano - Braziliano belt. The evolution of this belt can be summarized as the result of the convergence and collision between the São Francisco Congo cratons and the West African craton (WAC) and the Saharan metacraton defined by Abdelsalam et al. (2002). This mobile domain corresponds to the mobile belt of central Africa (Bessoles and Trompette 1980), which consists of an amalgamation of Precambrian terranes (Caby 1989; Castaing et al. 1994; Black and Liégeois 1993; Ferré et al. 1996, 2002) that show a long and complex crustal evolution with a strong overprint by the Neoproterozoic events. The most striking feature of this evolution is the presence of crustal-scale strike slip shear zones such as the Tchollire-Banyo fault (Fig. 1b) which to the Mayo Kebbi region is interpreted by some authors (Pouclet et al., 2006; Penaye et al., 2006) as the southern prolongation of the positive gravity anomaly identified in Chad (Louis, 1970). Cretaceous platform sediments (the Lame series) cover most of the Precambrian basement of this region, which is dominated by the felsic plutonic rocks, emplaced into metavolcanic-sedimentary series (Schneider and Wolff, 1992; Kasser, 1995; Penaye et al., 2006).

The Pala region located at Mayo Kebbi (Fig. 2) is characterized by NNE-SSW belt of low- to medium-grade Neoproterozoic schists (the Goueigoudoum schists) associated to the gneissamphibolite complex. All these rock units are intruded by syn- to post-tectonic plutonic rocks and crosscut by quartz veins.

The Goueigoudoum schists outcrop over a $30 \mathrm{~km}$ x $25 \mathrm{~km}\left(750 \mathrm{~km}^{2}\right)$ area between Torrok village in the north and Pala in the south where they disappear under the Cretaceous 
sediments (the Lame series). In the northern part, they are covered by thick soil and show only little bedrock outcrops. They consist of meta-andesites, talcschists (Fig. 3b), carbonatites interlayered with grey chloritoschists (Fig. 3a) and tuffaceous schists correspond to detrital arenaceous. Some massive strata in this sequence are descrived as metagabbros and metapyroxenites (Kasser, 1995; Moussa Isseini, 2011). Based on their geochemistry, tholeiitic signature of the metavolcanic of the Goueigoudoum series are related to an island arc or backarc basin tectonic (Kasser, 1995; Pouclet et al., 2006; Moussa Isseini, 2011; Moussa Isseini et al., 2012). At the Séré and Tikem villages, laterite cover is 0.5 to $1 \mathrm{~m}$ in thickness; nevertheless, the schists are observed in the wells of water suggesting the northern extension of the Goueigoudoum series.

The gneiss-amphibolite complex as defined by Schneider and Wolff (1992) is exposed west of the Goueigoudoum Series (Pala region) and is also found as numerous xenoliths within the granitoids. This complex dated at ca 750 Ma (Penaye et al., 2006; Moussa Isseini, 2011; Moussa Isseini et al., 2012) comprises hornblende-biotite gneisses interlayered with banded amphibolites; the presence of calc-silicate layers associated with amphibolite suggests that part of this unit is of sedimentary origin. According to Kasser (1995), and Penaye et al. (2006), this complex also includes meta-plutonic rocks with protolithes consisting dominantly of diorites associated with minor gabbros, norites, and peridotites. Kasser (1995) used the term "mafic to intermediate complex" as equivalent of the gneiss-amphibolite complex of Schneider and Wolff (1992).

The Pala granitoids outcropping around the Pala area belong to the Mayo Kebbi batholith which covers more than $50 \%$ of the Mayo Kebbi region in south western Chad. Based on $\mathrm{U}-\mathrm{Pb}$ and $\mathrm{Pb}-\mathrm{Pb}$ geochronological data (Penaye et al., 2006), three generations of plutonic rocks have been distinguished: the first generation is represented by metagabbrodiorite and metadiorite (Fig. 3c) emplaced between 737 and 723 Ma during an early phase of plate convergence. The second generation consists of tonalites, trondhjemites and granodiorites, emplaced during several magmatic pulses between 665 and $640 \mathrm{Ma}$. The third generation includes post- tectonic porphyric granodiorites (Fig. 3d) and hypersthene monzodiorites that have been dated at ca. 570 Ma (Penaye et al., 2006). Near the shear zones these granitoids are brecciated and cut by a stockwork of thin $(0.1-1.0 \mathrm{~cm})$ and variously oriented quartz and pyrite veinlets (Fig. 3c). 
The Cretaceous Lame series crop out at the west and south of Pala and they cover an area of about $2000 \mathrm{~m}^{2}$ areas. They consist mainly of conglomerates, sandstones, arkoses, clays, marls and metric lenses of shally limestone (Kasser, 1995).

The polyphasic evolution of the Pan-African orogeny has been established by Kasser, 1995; Doumnang, 2006; and Moussa Isseini, 2011, which defined three tectonic phases D1, D2 and D3.

The first tectonic phase is recorded by the metavolcanic-sedimentary rocks and the gneiss - amphibolite complex dated at about $750 \mathrm{Ma}$. This tectonic phase is characterized by a flat lying schistosity (S1) associated to isoclinal folds and E-W lineation.

The D2 deformation transposes D1 structures and develops upright folds within the Goueigoudoum volcanic-sedimentary series and the metadiorite (dated at about 737-723 Ma) associated with vertical foliations trending $\mathrm{N}-\mathrm{S}$ to NNE-SSW. In the two last groups of rock, it is marked by a second schistosity (S2) which is subvertical with N-S to NNE-SSW trend (Figs. 2, 4c and d).

The D3 deformation is related to NW-SE non penetrative foliation, sinistral strike-slip faults and dyke of quartz and joints (Figs $4 \mathrm{c}$ and $4 \mathrm{~d}$ ). It took place under conditions of increasing compression and local extension and was accompanied by the emplacement of porphyric granodiorites, hypersthene monzodiorite, and veins of quartz. Quartz veins and gold mineralizations seem to be spatially associated with brittle strike-slip faults (Fig. 4c).

\section{3.- Gold mineralization}

The number of gold camps in the Pala region is difficult to determine exactly: around 22 camps were registered by Deurdibaye Marambaye (2011), but in this study, we describe 13 sites of traditional gold exploitation are been visited. The most important mining localities include Gamboké, Mbidou, Bamdi, Massonebaré, and Goueigoudoum, all located north of Pala (Fig. 2). Both alluvial and primary gold deposits are found in these localities.

\section{1- Alluvial gold}

Exploitation of alluvial gold has been more important in the past. The alluvial gold occurs in 0.5-5 m thick "productive zones" of stone and gravel which contain up to $3.5 \mathrm{~g} / \mathrm{t} \mathrm{Au}$ (JIPROMIT, 1995; Table 1). Alluvial gold is mined in weathered zones (e.g. Mayo N'dala and Pougamaro rivers). The Mayo N'dala river and Bamdi encampment were in 2010 the most important alluvial and eluvial gold fields (Figs 4a and 4b). Gold extraction in 2010 was about $20.5 \mathrm{~g} \mathrm{Au}$ /day according to local authorities. The production area is several hundred 
meters long and up to $30 \mathrm{~m}$ wide. The most productive zone is found at the bottom of a $0.6-1$ $\mathrm{m}$ thick bed of stone and gravel overlying red brown clayish soil. The stone and gravel (1-40 $\mathrm{cm}$ ) consist mainly of milky and clear hydrothermal quartz. A few sugary quartz and finegrained granite, dacite and microdiorite pebbles are also observed. Up to $6-8 \mathrm{~m}$ of sand and soil is found above the productive layer.

\section{2- Primary native gold}

Primary native gold occurs in quartz tension gashes and shear veins in granitoids rocks and schists, at Gamboké, Massonébaré, Mbidou and Goueigoudoum localities where fine gold grains are observable directly in the rock samples (Fig. 4e). According to the field studies, three types of native gold ores are distinguished: Au-bearing quartz veins, mineralizations in brecciated and silicified zones within metagabbros and gold mineralizations related to shear zones.

\subsection{1- Au-bearing quartz veins}

The mineralizations are constituted by a network of quartz veins cross-cutting the schists (metavolcanic and metasedimentary rocks) and syn-to post-plutonic rocks. The shists are characterized by a general strike NE-SW and a dip of $70-90^{\circ}$ to the NW or SE. At Gamboke, they consist mainly of hydrothermally altered mica ( \pm chlorite) schist, interlayered with talcschist, metatuff and often metagraywacke. In thin section the schist is dominated by very fine-grained sericite, light green chlorite, calcite, ankerite and quartz. The sericite partly forms pseudomorphs after feldspar, and also occurs in small veinlets crosscutting the regional foliation.

Gold in these veins may be found in association with pyrite, arsenopyrite, and chalcopyrite (Fig.5a). The veins vary in thickness from few centimeters to 1.5 meter (Fig. 3e). Most of the veins strike WNW-ESE to NW-SE but, directions parallel to the N-S to NNE-SSW-trending S2 schistosity are also observed (Fig. 2). The directions are thus perpendicular or sub-parallel to the schistosity in hosting schist and plutonic rocks. The Au-bearing quartz veins generally truncate the $S 2$ foliation at the Goueigoudoum locality (Figs $4 \mathrm{c}$ and $4 \mathrm{~d}$ ), suggesting that they have formed during the late brittle stages of the deformation, but they display the same lateral, strike-slip kinematics and a consistent anticlockwise rotation of their trend relative to the Tcholliré-Banyo shear zone which is the southern prolongation of the Positive Gravity Anomaly (PGA) identified in Chad (Figs. 1b and 6).

\subsection{2-. Mineralizations in brecciated and silicified zones within a metagabbro}


This type of mineralization, which is described within a brecciated metagabbro sill (Fig. 3c), has been found in another shear zone located approximately $4 \mathrm{~km}$ east of the NNE-SSW trend Gaotao shear zone (Fig. 2). This metagabbro is sometimes replaced by extensively silicified chloritic rocks. The mineralization is located in the brecciated and silicified zones of the metagabbro, which contain an important sulfide mineralization represented by large cubic crystal of pyrite accompanied by magnetite and gold (Fig. 5b); others minerals are green amphibole (actinote), altered plagioclase, quartz, colorless to brownish amphibole (grunerite). This type of mineralization confined to basic intrusive rocks is interpreted as being of hydrothermal origin (Soo-Young and Se-Jung, 2001).

\subsection{3-. Mineralizations related to shear zones}

The most significant mineralization related to shear zones is hosted by the Gamboke shear zone at the limit separating the schists and metagabbros and Massonébaré shear zone where the talcschistes are brecciated by quartz veins (figure 2). The shear zones have been surveyed between Gamboké and Massonébaré along four NW-SE transects. Several shear structures with a NE-SW orientation have been recognized. These structures are subparallel, lenseform, 10-30 m wide and 150-350 m long. The metagabbro displays microgranular texture and is composed of fine grains of albite, quartz, biotite lamellae, sericite, chlorite, sulphides and oxides (Fig. 5c). The altered zone is composed of quartz, microcline, and accompanied by dispersed sulfide disseminations and visible native gold. The quartz crystals associated occasionally to sulfide and feldspar display deformation banding and development of subgrains along the grain boundaries (Fig. 3f). In the schists, gold-bearing pyrite is found as millimeter-wide beds of pyrite grains which are slightly elongated (Fig. 5d). Each lentiform structure is associated with a particular type of mineralizations: (1) mineralization enclosed in highly silicified talschist and metavolcanic rocks; (2) mineralizations closely related to an intensive silicification of metasedimentary rocks (chloritoschists) and (3) mineralizations encountered in brecciated and silicified zones within the amphibolo-pyroxenite and metagabbro sill.

The examples of mineralizations enclosed in highly silicified talschists and volcanic rocks include the southern Gouéigoudoum and Massonébaré locality which are associated with hydrothermally altered, silicified extrusive rocks. In detail, three lithological facies can be recognized in the mineralized zones:

- Dark-colored meta-andesites of doleritic texture, and in which the shistosity is underlined by chlorite and tremolite crystals; 
- Hydrothermally altered tuffs, which constitute the core of the mineralization zone; The alteration is characterized by chlorite, sericite, carbonates and silica;

- Quartz bearing tuffs.

Gold is mainly contained in pyrite beds associated with arsenopyrite within tuffs interbedded with meta-andesites and spillites. Gold is also associated with arsenopyrite, chalcopyrite and pyrite in quartz veins. The mineralization at Goueigoudoum and Massonébaré is interpreted as hydrothermal, although this mineralization appears to be controlled by lithology and deformation, the hydrothermal alteration is probably responsible for the concentration of gold in the silicified schists. The gold contents range between $0-33 \mathrm{~g} / \mathrm{t}$ with $5 \mathrm{~g} / \mathrm{t}$ in average at Massonébaré and 2.53g/t at Goueigoudoum (Table 1).

\section{4- Sulfide minerals analysis}

Some opaque minerals were analyzed using an electron microprobe at the joint microprobe laboratory of Centre National pour la Recherche Scientifique-University-Bureau de Recherches Géologiques et Minières of Orléans. One sample (PalTGG1) was from Goueigoudoum quartz vein with abundant chalcopyrite and small amounts of iron sulfides (Fig. 5a). The analyses show that the pyrite contains up to $3.3 \mathrm{wt} . \% \mathrm{Ni}$ and the pyrrhotite up to $2.1 \mathrm{wt} \% \mathrm{Ni}$. Analyses also identified sphalerite (Fe/Zn of 0.14-0.19) and suggested presence of $\mathrm{Fe}$ - bearing siegenite $\left((\mathrm{Ni}, \mathrm{Co}, \mathrm{Fe})_{3} \mathrm{~S}_{4}\right)$, the silver telluride hessite $\left(\mathrm{Ag}_{2} \mathrm{Te}\right)$, and a bismuth-telluride-selenide, probably kawasulite $\left(\mathrm{Bi}_{2}(\mathrm{Te}, \mathrm{Se}, \mathrm{S})_{3}\right)$. Another sample of a Gamboké schist associated to shear zone with elongated pyrite (Fig 5d) as the main opaque mineral contains talc and Fe- rich chlorite. The talc is a Fe-rich variety with up to $40 \% \mathrm{Fe}$.

\section{5- Whole rocks analysis}

Seven selected samples of schists (three talcschists and one metagabbro) and four felsic plutonic rocks were analysed for major, trace and rare earth element abundances by ICP-AES at the Centre de Recherches Pétrographiques et Géochimique (CRPG), Nancy-France. Analytical errors are $<5 \%$ for major elements and in the range $5-10 \%$ for trace elements and REE. Details of the analytical procedures is found in Govindaraju et al. (1976) and Govindaraju and Mevelle (1987). The analytical data are presented in Tables 2.

These rocks are affected by alteration and post-magmatic process, spilitization, weak thermal metamorphism and hydrothermal alteration. The major element contents may have been modified. The $\mathrm{SiO}_{2}$ vs. $\left(\mathrm{Na}_{2} \mathrm{O}+\mathrm{K}_{2} \mathrm{O}\right)$ diagram (Le Bas et al. 1986) is used for chemical classification (Figure 6a). The schist and metagabbro samples plot in the fields of gabbro whereas the granitoid samples plot in the diorite, syenodiorite and syenite fields. All the 
samples plot in the field of volcanic arc in the discrimination diagram based upon $\mathrm{TiO}_{2}-\mathrm{Zr}$ variations (Fig.6b) suggesting an active margin context for these rocks.

The schists have the following range in composition: $45.2<\mathrm{SiO}_{2} \%<47.81,0.01<\mathrm{TiO}_{2} \%<$ $1.08,9.15<\mathrm{MgO} \%<32.15$ and $0<\mathrm{Na}_{2} \mathrm{O}+\mathrm{K}_{2} \mathrm{O}<1.65$. They show high content values of transitional elements such as Co (47.76-87.61 ppm), $\mathrm{Cr}$ (390.6 - 2428 ppm), $\mathrm{Cu}$ (6.35-95.78 ppm), Ni (132.5-1563 ppm) and V (26.86 - 295.5 ppm). Chondrite normalized REE patterns of the schists show minor enrichment of LREE with respect to HREE (Figure 6c): $(\mathrm{La} / \mathrm{Yb})_{\mathrm{N}}=$ 2.79-3.17 and no $\mathrm{Eu}$ anomalies $\left(\mathrm{Eu} / \mathrm{Eu}^{*}=0.99-1.05\right)$. In the light of these observations, we suggest that talcschists are equivalent to metasomatized peridotites prior to their exhumation and mineralogical transformation.

One analysed metagabbro sample is characterized by low $\mathrm{SiO} 2$ content $(52.72 \% \mathrm{wt})$ and high $\mathrm{MgO}$ (5.95\%wt), $\mathrm{CaO}$ (7.99\%wt), $\mathrm{Cr}(101.3 \mathrm{ppm})$ and $\mathrm{Cu}(125.33 \mathrm{ppm})$. Its REE pattern is flat and do not show any significant Eu anomaly $\left(\mathrm{Eu} / \mathrm{Eu}^{*}=1.01\right.$; Fig. 6c).

The granitoid samples have intermediate silica contents (58.63-63.13 wt\%). All granitoid samples show moderate to high total alkali content (3.63-7.64\%), high $\mathrm{Al}_{2} \mathrm{O}_{3}$ (14.5$16.23 \% \mathrm{wt})$ and $\mathrm{Ba}(64.16-937.75 \mathrm{ppm})$ contents. The sample PALB3 is particularly richer in $\mathrm{Th}(25.07 \mathrm{ppm}), \mathrm{U}(6.61 \mathrm{ppm}) \mathrm{Zr}(518.12 \mathrm{ppm})$ and $\mathrm{Pb}(17.9 \mathrm{ppm})$. These rocks display less fractionated chondrite-normalised patterns with $(\mathrm{La} / \mathrm{Yb})_{\mathrm{N}}=11.82-13.35$, with the exception of sample PALB12 with less than $2 \%$. The REE pattern of these granitoid rocks show negative Eu anomaly $\left(\mathrm{Eu} / \mathrm{Eu}^{*}=0.61-0.86\right)$ and higher enrichment of LREE compared to the shist and metagabbro samples (Fig. 6c).

\section{6- Discussions}

The South West Chad is part of the NNE-SSW trending Neoproterozoic Central African Fold Belt (CAFB) and is made up of calc-alkaline granitoid suites emplaced between 737 and 570 Ma into a metavolcanic - metasedimentary sequence dated at $777 \pm 5$ Ma (Doumnang, 2006). This domain extends southward into Cameroon and is interpreted as middle Neoproterozoic arc stabilized at ca. $650 \mathrm{Ma}$ (Penaye et al., 2006). It is dominated by two main ductile deformation phases followed by regional strike-slip faults with the most important (Fig. 1b) are the Tchollire-Banyo shear zone, the central Cameroon shear zone, and the Sanaga shear zone.

The most significant late Neoproterozoic ore-forming events occurred near transcrustal shear zones as part of the Pan-African thermotectonic activity adjacent to many of Africa's cratonic blocks (Daly, 1988; Milési et al., 1989, 1992; Pohl and Gunther 1991; Agar, 1992; Pohl 1994; 
Worku, 1996 and Lang et al., 2000). In all cases, the orogenic gold deposits are related to terranes in which new volcano-sedimentary sequences were formed, rather than in terranes in which only pre-existing crust was reworked (Solomon et al., 1994). Two factors control the gold mineralization in the Pala region: (i) lithology: the mineralization is confined to quartz veins, and silicified and brecciated within a metagabbro; (ii) tectonics: the mineralization is restricted to shear zones.

Firstly, primary gold in the Pala region is hosted by quartz veins, shear veins and brecciated and silicified zones. As discussed above these veins cross cut meta- volcanosedimentary rocks, related to major ductile NNE-SSW shear zones also affecting the granitoids. The NESW shear zones of Pala region could represent the prolongation of the Tcholliré-Banyo shear zone (TBSZ) of Cameroon (Fig. 6), which is known to host several important gold deposits (Mbé, Gamba, Landou, Tcholliré, Mayo Rey and Poyémé localities for example). The TBSZ defines the boundary between the Adamawa-Yadé Domain (AYD) which represents a Paleoproterozoic basement that was dismembered during the Pan-African orogeny and the Northern Domain (ND) located west of TBSZ. The ND extends along the Mayo Kebbi Region (MKR) at SW Chad and is considered as the eastern prolongation of the northeastern Nigeria terrane (Fig. 1) including schists and gneisses of southeastern Nigeria (Ferré et al., 2002; Ekwueme and Kröner, 1998). This shear zone which continues into Chad along an important linear heavy gravity anomaly (Fig. 6) described by Louis (1970) is interpreted as a terrane boundary between a northwestern domain dominated by younger crust and the disrupted northern portion of the Congo-Sao Francisco craton (Toteu et al., 2004; Van Shmus et al., 2008). According to Pouclet et al. (2006) the Tcholliré shear zone is the accreted zone of the arc system that constitutes the Léré-Poli Terrane. This area preserves geophysical evidence for crustal thinning from the Adamaoua-Yade Block to the Léré-Poli Terrane (Dorbath et al., 1984). The position of Pala rock samples in the volcanic -arc domain (Fig. 6b) support this interpretation. Gold-bearing quartz veins have been identified in extensional fractures within greenschist facies rocks of the Mayo Rey group (Cameroon) and Goueigoudoum meta- volcanosedimentary rocks. The veins may be interpreted to have formed within the uplifting rocks during the Pan-african orogen.

This major crustal-scale shear zone is a typical structural setting for most orogenic gold deposits (Goldfarb et al., 2005) and is regarded as major conduits for auriferous fluids, and this is probably also the case for the deposits in the Pala gold. These conduits are most likely late Pan-African shear structures, developed in the central African fold belt (Fig. 6). 
Second, the mineralogy of the brecciated and silicified metagabbro in the Pala region is quartz, plagioclase with subordinate pyrite, magnetite, chlorite, carbonate and Fe-amphibole (Fig. 4a). This is a classic mineral assemblage for mesozonal-metamorphic gold deposits (Milési et al., 1992). Arsenopyrite is common in many deposits where metasedimentary rocks are part of the host lithology (Hodgson, 1993; Goldfarb et al., 2005), whereas pyrite is the most common iron sulfide where the host is a mafic rock (Fig. 4a).

The Pala granitoids are accompanied by hydrothermal alteration in the contact aureole, in apical portions of intrusive bodies, and along dike margins. The altered rocks attract interest as an ore-forming medium with respect to gold-sulfide and gold-quartz mineralization. The alteration in the outer contact zone of quartz diorite and granite porphyry cutting metavolcanosedimentary rocks corresponds to high-temperature propylitization and is characterized by intense biotitization and formation of epidote, actinolite, tremolite, and carbonate and accompanied by sulfide-bearing carbonate-quartz veinlets and pyrite disseminations in amphibolites and tremolite schists. Numerous low-sulfide and sulfide-free quartz veins occur in meta-andesite to the East of the Bougaraou intrusion (Fig. 2).

The main stage of gold mineralization in the Goueigoudoum neoproterozoic schist series is related to the Pala pan-African granitoids (Penaye et al., 2006 and Moussa Isseini, 2011). Most of these intrusive bodies are localized in the western and eastern parts of the schist series and all the rocks are cross cutted by regional NNE-trending strike-slip fault zones. The probable hydrothermal nature of the gold deposits in the Pala region, as inferred from their apparent contemporaneity with the silica-carbonate gangue, suggests that the origin of the hydrothermal fluids may be sought in the Pan-African tectonothermal event. Although the origin of fluids may be varied (magmatic, metamorphic or meteoric fluids, Proterozoic seawater, or sedimentary basin formation waters), the distribution for the mineralizations along the granitoid intrusion suggests that magmatism played a major role in the dynamics of the mineralizing fluids. Geological context of the Pala region clearly indicates hydrothermal fluids formed along active continental margins during collisional orogenesis, and subsequent associated fluid migration typically occurred during strike-slip events.

\section{Conclusion}

The geology of the Pala region (South West of Chad) mainly consists of volcanic, volcaniclastic, and sedimentary rocks of Neoproterozoic age which are intruded by granitoids. One of the features of this region is the presence of NNE-SSW shear zone and veins of quartz. The gold mineralization was formed during several stages, beginning from low-grade ore and 
dispersed concentrations in zones of hydrothermal alteration and sulfidation in the Goueigoudoum schist series which is the equivalent of Zalbi series dated at $777 \pm 5 \mathrm{Ma}$ (Doumnang, 2006) or 700 Ma (Moussa Isseini, 2011; Moussa Isseini et al., 2012) and ending with disseminated and stockwork mineralization hosted in brecciated and silicified metagabbro.

Primary gold fields in the Pala region consist of shear zone mineralization, brecciated and silicified zones within a metagabbro and sulfide- bearing quartz veins hosted in granitoids and schist. In the Goueigoudoum schist series, the quartz veins are characterized by a mineral assemblage of chalcopyrite, pyrite with accessory tellurides and gold. The richest occurrence is at Gamboké localitie and contains $33 \mathrm{~g} / \mathrm{m}^{3}$ of $\mathrm{Au}$ (Soo-Young and Se-Jung, 2001; Deudibaye Marambaye, 2011).

The quartz veins generally trend $\mathrm{N}-\mathrm{S}$ to NNE-SSW or NW-SE and are interpreted as extensional shear fractures related to regional NE-SW-trending strike-slip shear zones. This shear zones have a similar trend and P-T metamorphism condition (greenschist- to amphibolite- facies) such as the Tchollire-Banyo shear zone (Fig. 6; Pinna et al., 1994) which hosts several important gold deposits in north Cameroon (e.g., Mayo Rey, Gamba, Mbé, ...). The tectonic significance of these NE-SW strike-slip structures remains unclear, but could be related to a regional phase of late Pan-African extension, which is well-defined further east in Cameroon and Southern Chad by positive gravity anomalies (Louis, 1970). A number of vein quartz mesothermal gold deposits, are genetically linked to this structure, and the structure should have a certain potential for finding new gold deposits. Gold is observed either as free gold, or in association with pyrite, and chalcopyrite. The fact that the gold deposits are mainly of hydrothermal origin and the distribution of these deposits along the Pala granitoids suggests that magmatism has played a major role in the dynamics of the mineralizing fluids. In conclusion, the following points best summarize present understanding of the gold mineralization of the Pala region:

(1) The gold deposit is characteristically associated with deformed and metamorphosed mid-crustal blocks, particularly in spatial association with a NE-SW major crustal structure (the Tcholliré-Banyo shear zone). This mineralization belongs to the orogenic gold deposits.

(2) Ore formation occurred during Pan-African events in the Central Panafrican Fold Belt, within the schist and granitoids which accreted in an arc volcanic context; 
(3) Three types of native gold are distinguished: Au-bearing quartz veins, mineralizations in brecciated and silicified zones within a metagabbro and gold mineralization related to shear zones.

(4) The quartz veins are characterized by a mineral assemblage of chalcopyrite, pyrite, with accessory gold. The gold deposits are classified as mesozonal and metamorphic in origin, based on their occurrence, style of alteration in the host rock and relation to regional structure.

(5) Geological context of the Pala region clearly indicates hydrothermal fluids formed along active continental margins during collisional orogenesis, and subsequent associated fluid migration typically occurred during strike-slip events. Although the origin of fluids may be varied (magmatic, metamorphic or meteoric fluids, Proterozoic seawater, or sedimentary basin formation waters), the distribution for the mineralization along the granitoid intrusion suggests that magmatism played a major role in the dynamics of the mineralizing fluids

(6) We propose to extend this study along the Tchollire - Banyo fault which lies within the strike of the positive gravimetric anomaly defined by Louis (1970) and is a major crustal-scale shear zone. A number of vein quartz mesothermal gold deposits, are genetically linked to this structure, and the structure should have a certain potential for finding new gold deposits.

\section{Acknowledgements}

The authors thank the French cooperation which financed field work. This study is a contribution for the AUF PCSI 603 Project and AUF-51011SU201 The AUF (Agence Universitaire de la Francophonie) support is gratefully acknowledged. Special thanks are due to Olivier Rouer for his assistance during mineral analysis. Dr. Mark Jessel and Dr. Moussa Isseini are thanked for their constructive reviews and valuable suggestion for the improvement of an earlier version of this paper. 


\section{References}

Abdelsalam, M.G., Liégeois, J.P., Stern, R.J., 2002. The Saharan metacraton. Journal of African Earth Sciences 31: 119-136.

Agar, R.A., 1992. The tectono-metallogenic evolution of the Arabian Shield. Precambrian Res. 58, 169-194.

Bessoles, B., Trompette, R., 1980. Géologie de l'Afrique. La chaîne panafricaine "“zone mobile d'Afrique centrale»", (partie sud) et zone soudanaise. Mémoire BRGM, Orléans, vol. 92, p. 394.

Bjerkgard, T., Stein, H.J., Bingen, B., Henderson, I.H.C., Sandstad, J.S., Moniz, A., 2009. The Niassa Gold Belt, northern Mozambique - A segment of a continental-scale PanAfrican gold-bearing structure? Journal of African Earth Sciences 53: 45-58.

Black R., Liegeois, J.-P., 1993. Cratons, mobile belts, alkaline rocks and continental lithospheric mantle: the Pan-African testimony. Journal of the Geological Society, London 150, 89-98.

Caby R., 1989. Precambrian terrane of Benin-Nigeria and Northeast Brazil and Proterozoic Atlantic. Geol. Soc. Am., sp. paper, 230; 145-158.

Castaing C., Feybesse J.-L., Thiéblement D., Triboulet C., Chèvremont P., 1994. Paleogeographical reconstructions of the Pan-African/Brasiliano orogen: closure of an oceanic domain or intracontinental convergence between major blocks. Precambrian Research 69: 327-344.

Chaussier, J. B. 1970. Carte minérale du Tchad \& notice. Rapport inédit 68p. Direction Mines Géologie, Fort Lamy (N'Djaména).

Daly, M.C., 1988. Crustal shear zones in central Africa: a kinematic approach to Proterozoic tectonics. Episodes 11, 5-11.

Deurdibaye Marambaye, 2011. Contexte géologique, typologie des gisements de l'or de Pala (Sud Ouest du Tchad) et impacts socio-environnementaux liés à leur exploitation artisanale. Mémoire de Master ; Université de Ngaoundéré. 57 p.

Djekoundam, M., 1995. Géologie et Potentiel Minier du Tchad. Ministère des Mines, de l'Energie et du Pétrole. N’Djaména Tchad.

Dorbath, L., Dorbath, C., Stuart, G., Fairhead, D., 1984. Structure de la croûte sous le plateau de l'Adamoua (Cameroun). Comptes Rendus de l'Académie des Sciences, Paris 298, 539-542. 
Doumnang, J.C., 2006. La géologie des formations néoprotérozoïques du Mayo Kebbi, Sud Ouest du Tchad. Thèse de Doctorat d'Université d'Orléans (France), 234p.

Ekwueme, B.N., and Kröner, A. 1998. Single zircon evaporation ages from the Oban massif, southeastern Nigeria. Journal of African Earth Sciences, 26: 195-205.

Ferré E., Gleïzes G. et Caby, R., 2002. Obliquely Convergent tectonics and granite emplacement in the trans-saharan belt of Eastern Nigeria: a synthesis. Precambrian Reseach 114 : 199-219

Ferré E.C., Déléris J., Bouchez J.L., Lar A.U., Peucat J.J., 1996. The Pan-African reactivation of contrasted Eburnean and Archean provinces in Nigeria: structural and isotopic data. Journal of the Geological Society, London 153: 719-728.

Govindaraju, K., Mevelle, G., 1987. Fully automated dissolution and separation methods for inductively coupled plasma atomic emission spectrometry rock analysis. Application to the determination of rare earth elements. Journal of Analytical Atomic Spectrometry2, 615-621.

Govindaraju, K., Mevelle, G., Chouard, Ch., 1976. Automated optical emission spectrochemical bulk analysis of silicate rocks with microwave plasma excitation. Analytical Chemist 48, 1325-1331.

Goldfarb, R.J., Baker, T., Dubé, B., Groves, D.I., Hart, C.J.R., Gosselin, P., 2005. Distribution, character, and genesis of gold deposits in metamorphic terranes. Economic Geology 100th Anniversary Volume, pp. 407-450.

Goldfarb, R.J., Groves, D.I., Gardoll, S., 2001. Orogenic gold and geologic time: a global synthesis. Ore Geology Reviews 18: 1-75.

Hodgson, C.J., 1993. Mesothermal lode-gold deposits. In: Kirkham, R.V., Sinclair, W.D., Thorpe, R.I., Duke, J.M. (Eds.), Mineral deposit modeling. Geological Association of Canada, Special Paper 40, pp. 635-678.

Moussa Isseini, M., 2011. Croissance et différenciation crustales au Néoprotérozoïque. Exemple du domaine panafricain du Mayo Kebbi au Sud-Ouest du Tchad. Thèse de doctorat de l’Université Henri Poincaré, Nancy I. 345p.

Moussa Isseini, André-Mayer A-S., Vanderhaeghe O., Barbey P., Deloule E., 2012. A-type granites from the Pan-African orogenic belt in south-western Chad constrained using geochemistry, $\mathrm{Sr}-\mathrm{Nd}$ isotopes and U-Pb geochronology. Lithos 153 (2012) 39-52

JIPROMIT, 1995. Journées Internationales de la Promotion du secteur minier. Du 26 au 30 novembre 1995. PNUD-République du Tchad. Volume des exposés. 64 pages 
Kasser, M. Y., 1995. Evolution précambrienne de la region de Mayo Kebbi (Tchad), un segment de la chaîne panfricaine. Thèse de Doctorat au Muséum National d'Histoire Naturelle de Paris, 217p.

Kuleshevicha, L. V., Furman, V. N, 2009. The Taloveis Gold Deposit in the Precambrian Kostomuksha Greenstone Belt, Karelia. Geology of Ore Deposits 51, º1, pp. 51-67.

Kusnir I., 1991. Minéralisation de l'or dans le Mayo Kebbi. Rapport de mission au Mayo Kebbi, 20p.

Kusnir, I., Moutaye, H.A., 1997. Ressources minérales du Tchad: une revue. Journal of African Earth Sciences 24 : 549-562.

Lang, J.R., Baker, T., Hart, C.J.R., Mortensen, J.K., 2000. An exploration model for intrusion-related gold systems. SEG. Newsl. 40 1, 6-15.

Le Bas, M.J., Le Maitre, R.W., Streckeisen, A., and Zanettin, B., 1986, A chemical classification of volcanic rocks based on the total-alkali-silica diagram. Journal of Petrology, v. 27, p. 745-750.

Louis, P., 1970. Contribution géophysique à la connaissance géologique du bassin du Lac Tchad. Mémoires ORSTOM, Paris, 308.

Mahamat Boka R., 2010. Etude pétrographique, structurale et cartographique des formations géologiques de la région de Pala (Sud - Ouest du Tchad): implications métallogéniques. Mémoire de Master ; Université de Dschang. 128p.

McDonough, W.F., and Sun, S.S., 1995, The composition of the Earth: Chemical Geology, v. 120 , p. $223-253$.

Milési, J.P., Feybesse, J.L., Ledru, P., Dommanget, A., Ouédraogo, M.F., Marcoux, E., Prost, A., Vinchon, C., Sylvain, J.P., Johan, V., Tegyey, M., Calvez, J.Y., Lagny, P., 1989. Les minéralisations aurifères de l'Afrique de l'Ouest. Leurs relations avec l'évolution lithostructurale au Protérozoïque inférieur. Chronique de la recherche Minière 497, 3 98.

Milési, J.P., Ledru, P., Feybesse, J.L., Dommanget, A., Marcoux, E., 1992. Early proterozoic ore deposits and tectonics of the Birimian orogenic belt, West Africa. Precambrian Research 58, 305-344.

Nesterenko G.V. and Kolpakov V.V., 2010. Allochthonous Native Gold in Piedmont Alluvium in the Southern West Siberia. Lithology and Mineral Resources 45, N5, pp. 425-442. 
Nzenti J.P., Barbey P. Macaudière J. and Soba D., 1988. Origin and evolution of the late Precambrian high grade Yaounde gneisses (Cameroon). Precambrian Research 38, 91109.

Penaye J., Kröner, A., Toteu, S.F., Van Schmus, W.R., Doumnang, J.C., 2006. Evolution of the Mayo Kebbi region as revealed by zircon dating: An early (ca. $740 \mathrm{Ma}$ ) PanAfrican magmatic arc in southwestern Chad. Journal of African Earth Sciences 44: $530-542$.

Pearce, J.A., Harris, N.B.W., Tiindle, A.G., 1984. Trace element discrimination diagrams for the tectonic interpretation of granitic rocks. Journal Petrology 25, 956-983.

Pinna P., Calvez J Y., Abessolo A., Angel J.M., Mekolou Mekoulou T., Managa G., Vernet Y. 1994. Neoproterozoic events in the Tcholliré area: Panafrican crustal growth and geodynamic in central-northen Cameroun (Adamawa and north Provinces). Journal of African Earth Sciences 18: 347-353

PNUD/Projet/CHD/87/010/DRGM (1987). Rapport sur la prospection de l'or dans le Mayokebbi. 20 p.

Pohl, W., 1994. Metallogeny of the northeastern Kibara belt, central Africa-recent perspectives. Ore Geol. Rev. 9, 105-130.

Pohl, W., Gunther, M.A., 1991. The origin of Kibaran late. Mid-Proterozoic tin, tungsten, and gold quartz vein deposits in Central Africa: a fluid inclusion study. Miner. Deposita 26, 51-59.

Poidevin J.L., 1983. La tectonique panafricaine à la bordure du craton congolais: l'origine des "Oubanguides". XII ème Coll. Géol. Afr., Bruxelles: 6-8.

Pouclet, A., Vidal M., Doumnang, J.C., Vicat, J-P., Tchameni, R., 2006. Neoproterozoic crustal evolution in Southern Chad: Pan-African ocean basin closing, arc accretion and late- to post-orogenic granitic intrusion. Journal of African Earth Sciences 44: 543560

Schneider, J.-L. 1989. Géologie et hydrogéologie de la République du Tchad. Thèse Université d'Avignon, France. 547p.

Schneider, J.L., Wolff, J.P., 1992. Carte géologique et cartes hydrogéologiques à 1/500.000 de la République du Tchad. Mémoire explicatif. Document du BRGM 209, 2 volumes.

Solomon, M., Groves, D.I., 1994. The Geology and Origin of Australia's Mineral Deposits. Oxford Monogr. Geol. Geophys. vol. 24. Clarendon Press, Oxford, 951 pp. 
Soo-Young, Se-Jung, 2001. Fluid inclusion and stable isotope studies of gold deposits in the Ganboke mineralized district, Pala area, Chad. Geosciences Journal, vol 5. № 1 p 27 45.

Toteu, S.F., Penaye, J., Poudjom Djomani, Y.H., 2004. Geodynamic evolution of the PanAfrican belt in Central Africa with special reference to Cameroon. Canadian Journal of Earth Sciences 41: 73-85.

Worku, H., 1996. Structural control and metamorphic setting of shear zone-related Au vein mineralization of the Adola Belt (southern Ethiopia) and its tectonogenetic development. J. Afr. Earth Sci. 23, 383-409.

Van Schmus W. R., Oliveira E. P., da Silva Filho A. F., Toteu S. F., Penaye J., Guimarães I.P., 2008. The Central African Fold Belt Proterozoic links between the Borborema Province, NE Brazil, and the Central African Fold Belt. Geological Society, London, Special Publications, v. 294; p. 69-99. 


\section{Table and figure captions}

Figure 1. (A) Sketch map showing the location of Fig. 1b. 1, Post-Pan-African cover; 2, PanAfrican belt; 3, pre-Mesozoic platform series; 4, Archean to Paleoproterozoic cratons; 5, craton limits; 6, faults; 7, State boundaries. CAR, Central African Republic; CM, Cameroon. (B) Geological sketch map of the Pan-African orogenic belt north of the Congo craton. Redrawn after Pinna et al (1994) and Toteu et al. (2004). 1, Cenozoic volcanic rocks of the Cameroon line; 2, Mesozoic sediments; 3, Southern domain (SD); 4, northern domain (ND); 5, Adamawa-Yadé domain (AYD); 6, Congo craton (CC); 7, thrusts; 8, faults: TBSZ, Tcholliré-Banyo shear zone; CCSZ, central Cameroon shear zone; SSZ, Sanaga shear zone; SCSZ, southwest Cameroon shear zone. MKR, Mayo Kebbi Region; PGA, Positive Gravity Anomaly.

Figure 2: Geological sketch map of the Pala region showing location of the analyzed samples. 1) Cretaceous Lamé series; 2) Late- and Post-collisionnal plutonic rocks (granite, syenite, trondhjemite, diorite); 3) Metagabbro; 4) Amphibolo pyroxenite; 5) Goueigoudoum Series (chloritoschiste, sericitoschiste, talcschiste); 6) Quartz dykes; 7) S2 Schistosity; 8) Faults; 9) artisanal gold site exploitations; 10) analyzed samples. The Stereonets show the shear zone schistosity (filled circles)-quartz vein (open circles) geometry relationships.

Figure 3: Field observation-based sketch showing principal types of rocks: A) chloritoschist at Zama Gouin; B) Talcschist at Goueigoudoum; C) Brecciated and silicified zone within a metagabbro; D) porphyric granite cross cut by Au mineralized quartz vein under artisanal exploitation at Goueigoudoum; E) quartz veins observed at Massonébaré.

Figure 4: Gold fields in Pala region: A) Bamdi (South of Goueigoudoum) encampment; B) Artisanal gold workers in the Mayo N'dala River; C) Gold bearing quartz veins associated with the brittle sinistral shear zone in metadiorite at Goueigoudoum; D), Stereonet showing the foliation-quartz veins geometry relationships at Goueigoudoum; E), Crystals of gold in quartz hand specimen from Gouéigoudoum gold field.

Figure 5: Photomicrographs of thin sections of: A) quartz vein sample shows a large chalcopyrite crystal; B) Hydrothermally altered brecciated metagabbro; C) Metagabbro with recristalized quartz, sericite, chlorite, sulphides and oxides; D) mylonitic schist with elongated pyrite (sample PalGS7). Minerals abbreviations: Amph: Amphibole ; Bi: Biotite; Chl: Chlorite; 
CPyr : Calcopyrite; Fe-Amph: Ferro amphibole; Pl: Plagioclase; Pyr: Pyrite; Qz: Quartz; Ox : Oxides ; Ser: Sericite.

Figure 6: (A) Metavolcanic and plutonic rocks plotted in diagram of total alkalis vs. $\mathrm{SiO}_{2}$ (diagram from LeBas et al., 1986). The thick line separates alkaline and sub-alkaline rocks (from Irvine and Baragar, 1971). (B) The TiO2 vs. Zr diagram from Pearce (1982). (C) Chondrite-normalized REE patterns for the selected Pala rocks. Normalization values are from McDonough and Sun (1995); schists (square); metagabbro (triangle) and granitoid (circle).

Figure 7: Geological sketch map of central Africa showing Massenia-Ounianga Heavy Gravity Anomaly (HGA) in Chad and its possible southward prolongation along the Tcholliré-Banyo Shear Zone (TBSZ). 1) Cretaceous sediments; 2) Remobilized basement (Western Nigeria and Central Hoggar); 3) Neoproterozoic metavolcanic and metasedimentary rocks; 4) Neoproterozoic domain without Archean inheritances (North Cameroon, Tibesti, Eastern Hoggar); 5) Paleoproterozoic basements or assumed (Adamawa - Yadé domain, central massif and Waddaï); 6) Faults; 7) Gold mineralization fields localized along the TBSZ.

Table 1: Structures of some occurrences and their gold

Table 2: Whole-rock data of selected metamorphic and plutonic rocks in the Pala Gold Field. 

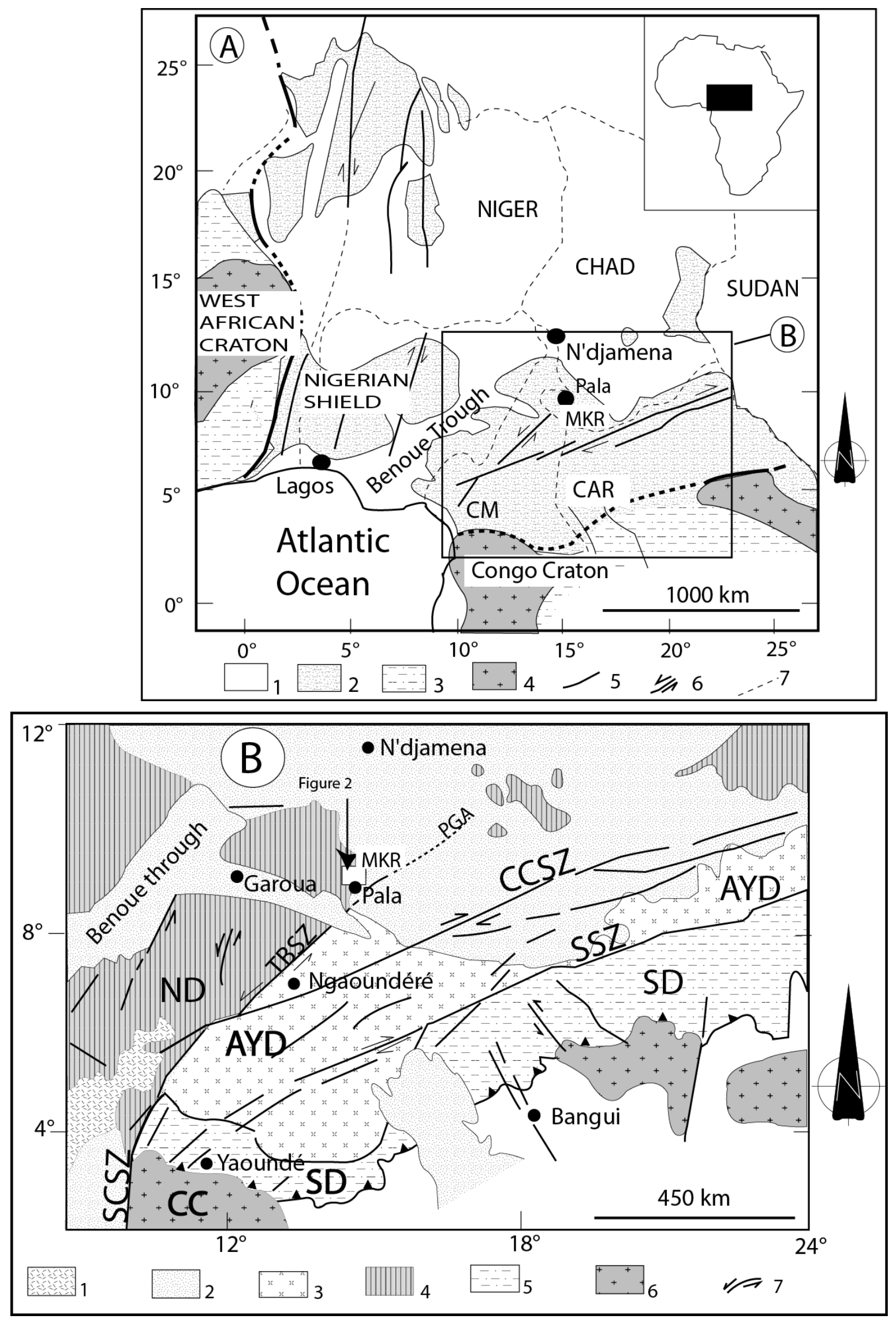

Figure 1 


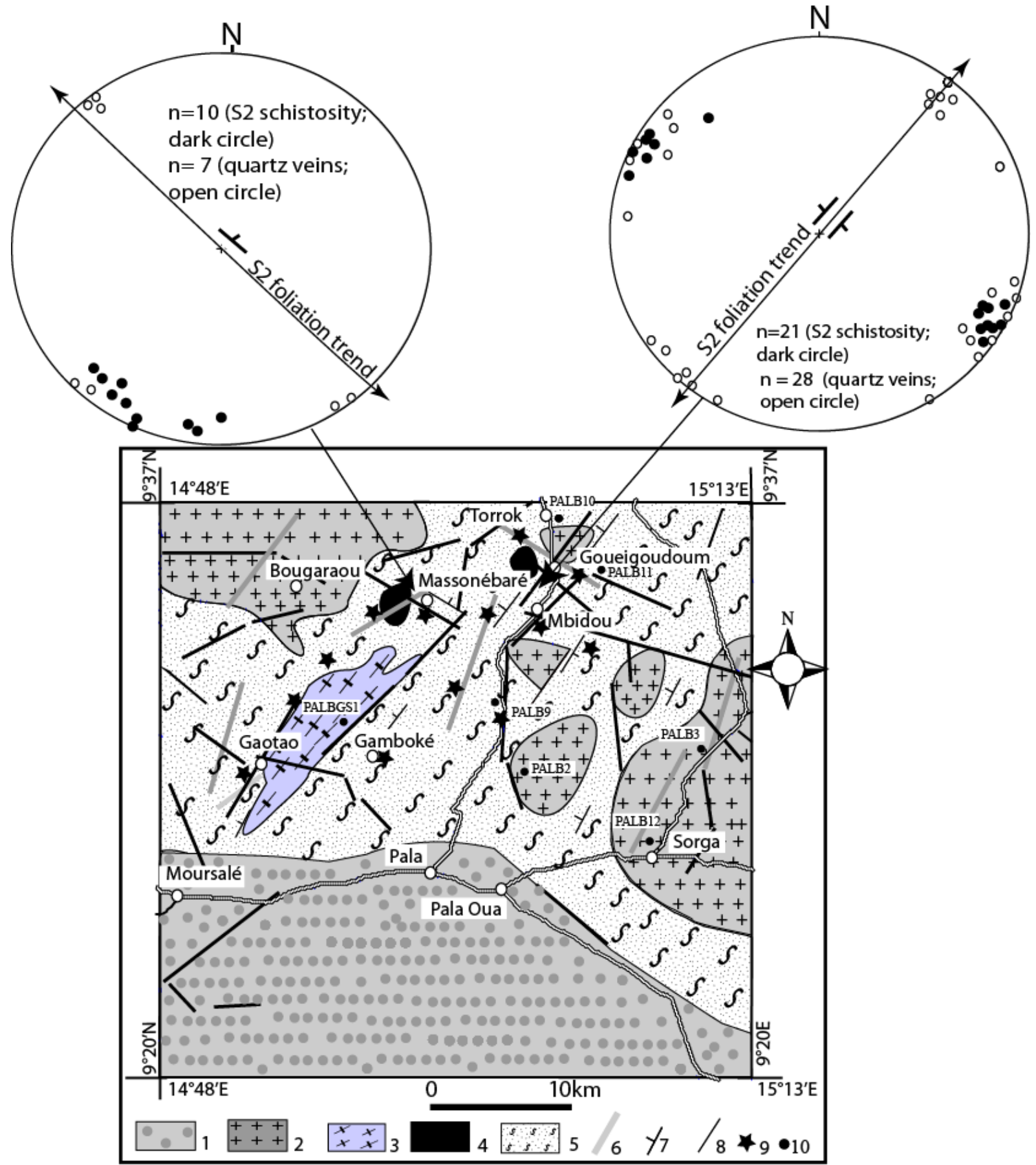

Figure 2 

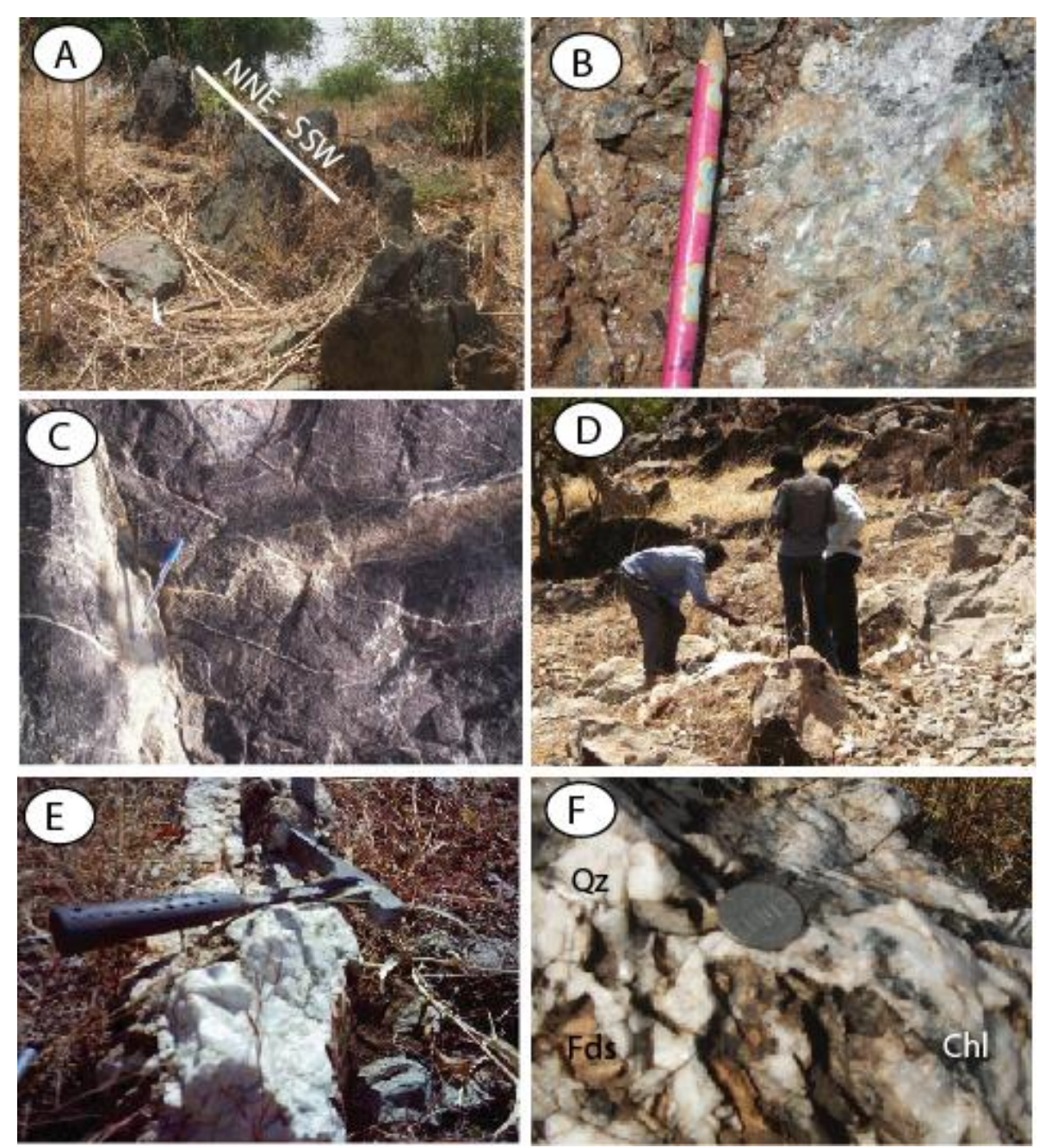

Figure 3 

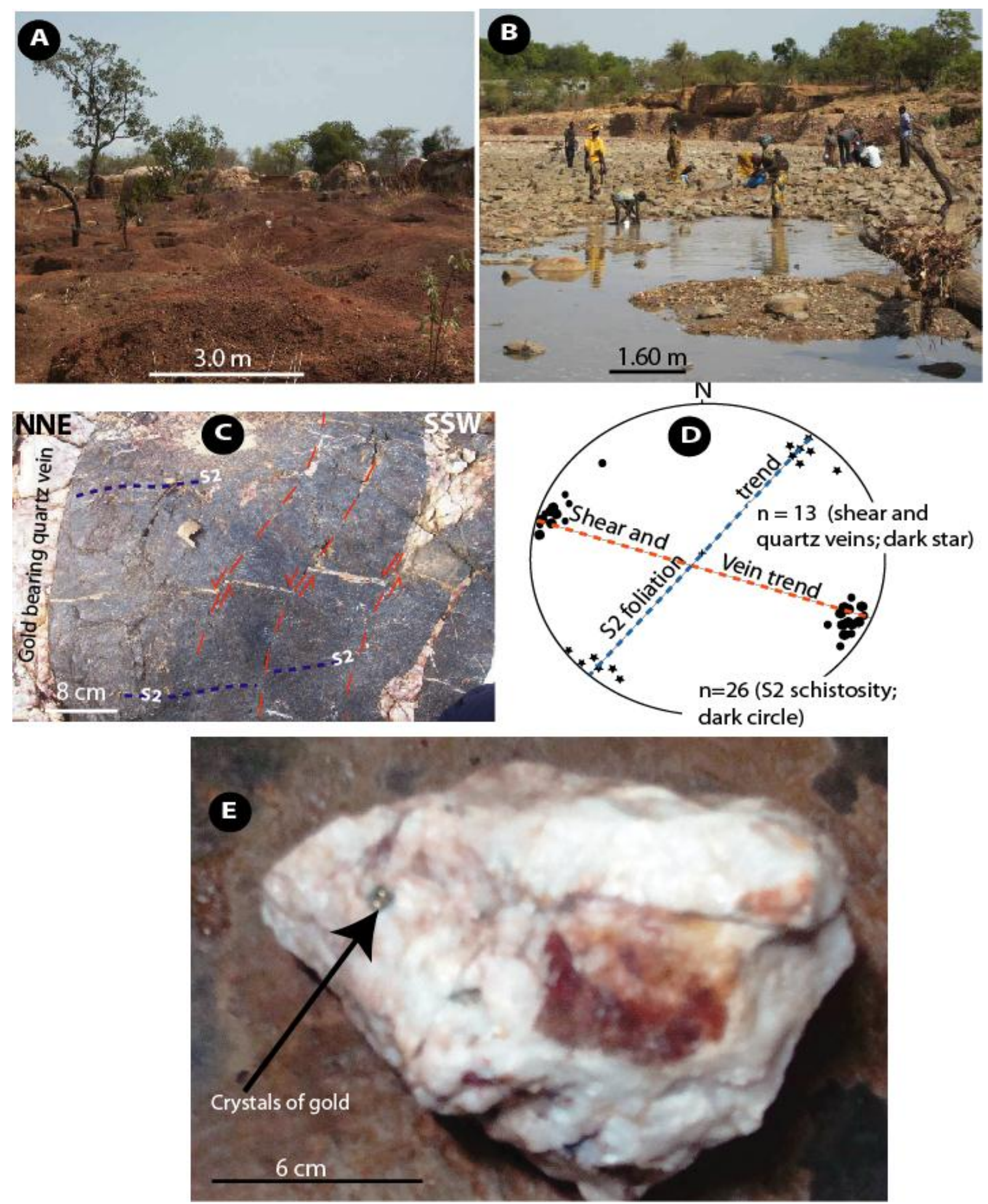

Figure 4 

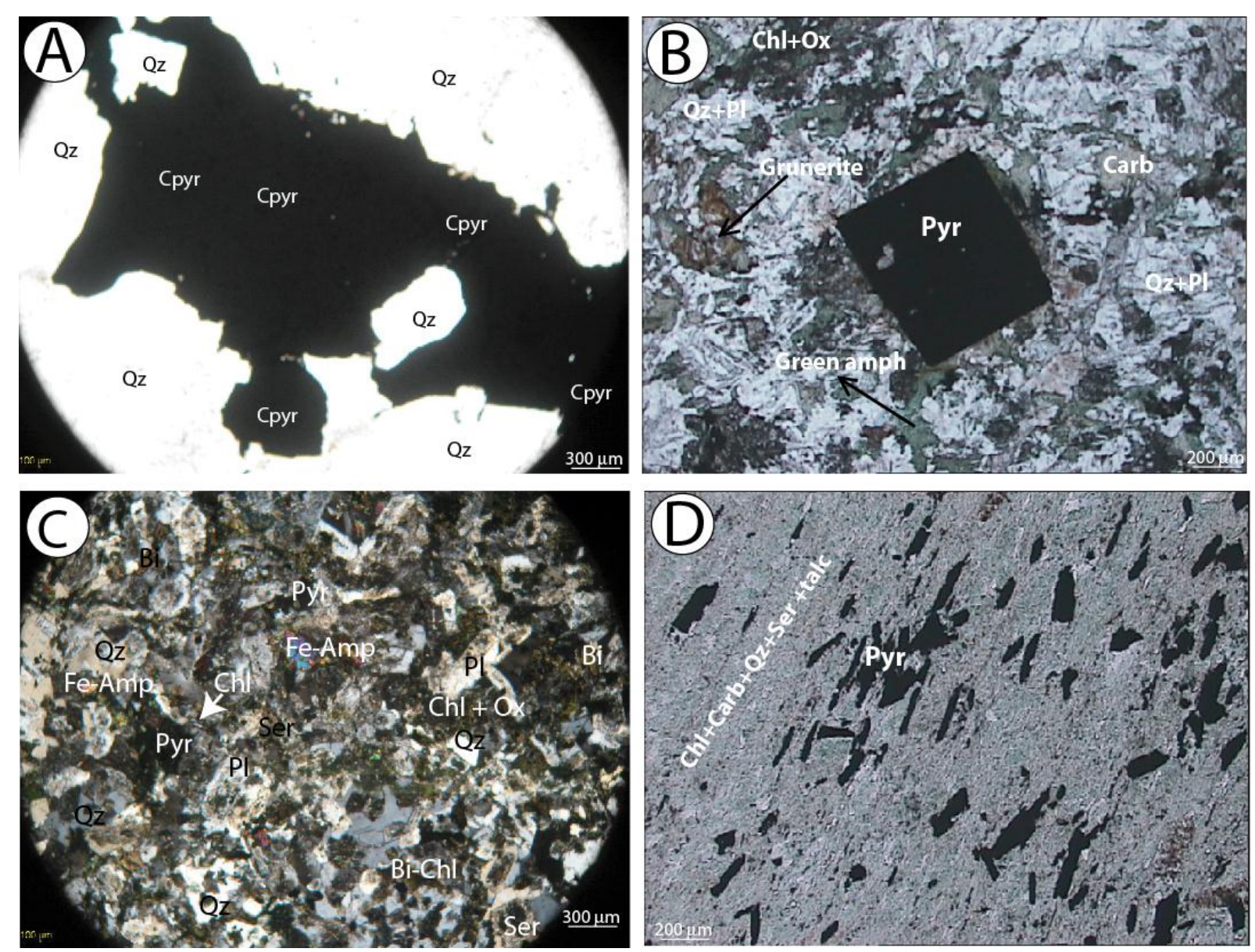

Figure 5 


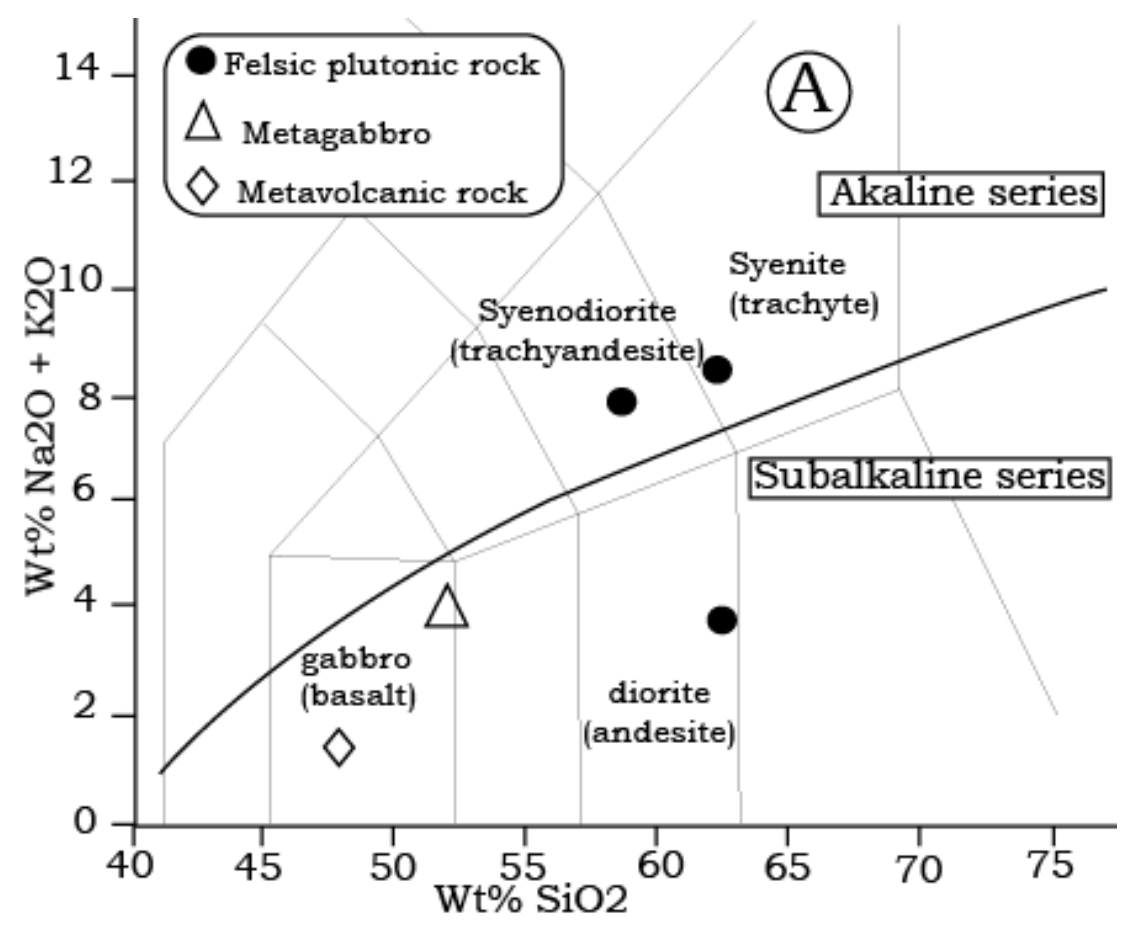


Figure 6a

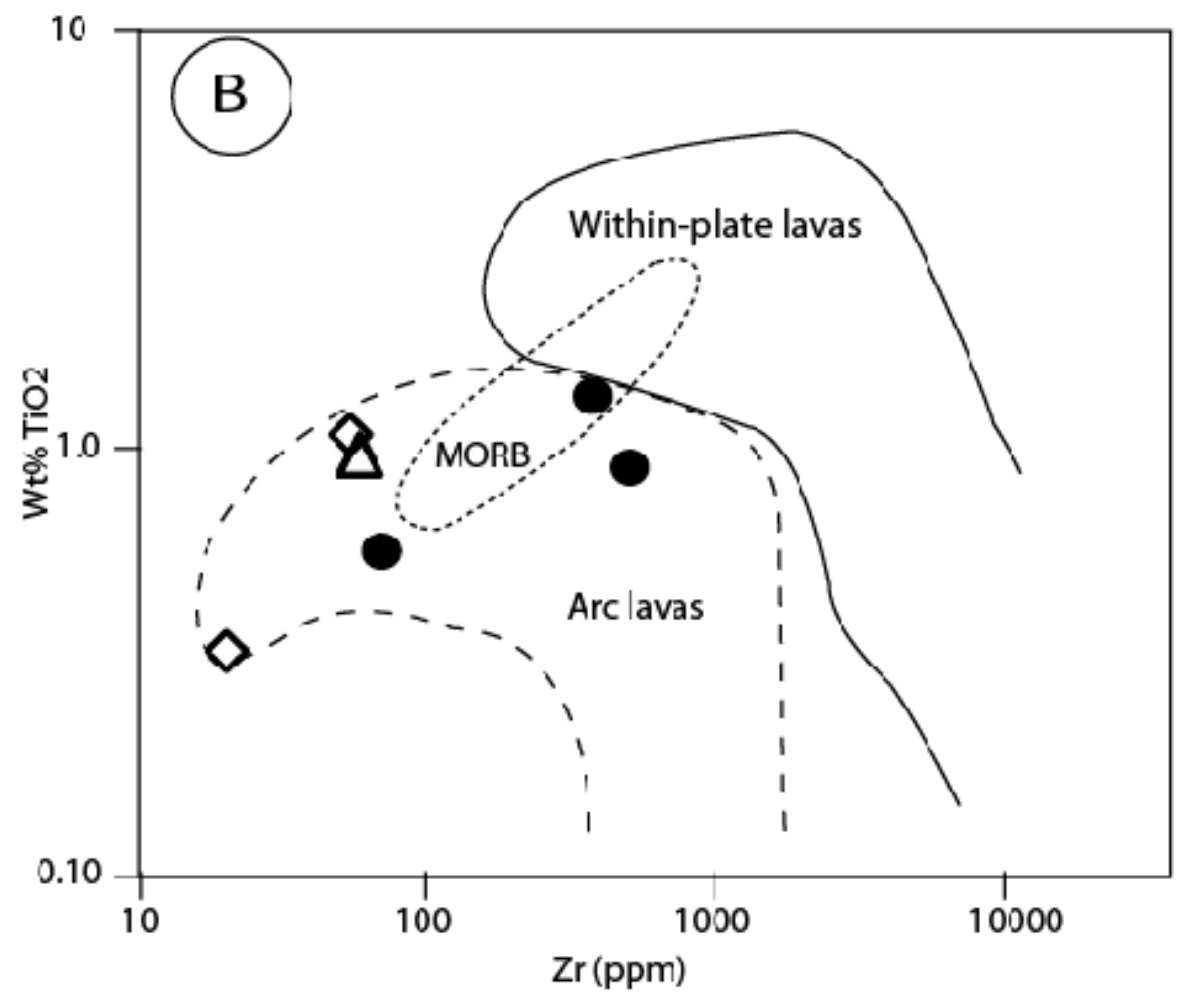

Figure $6 b$ 


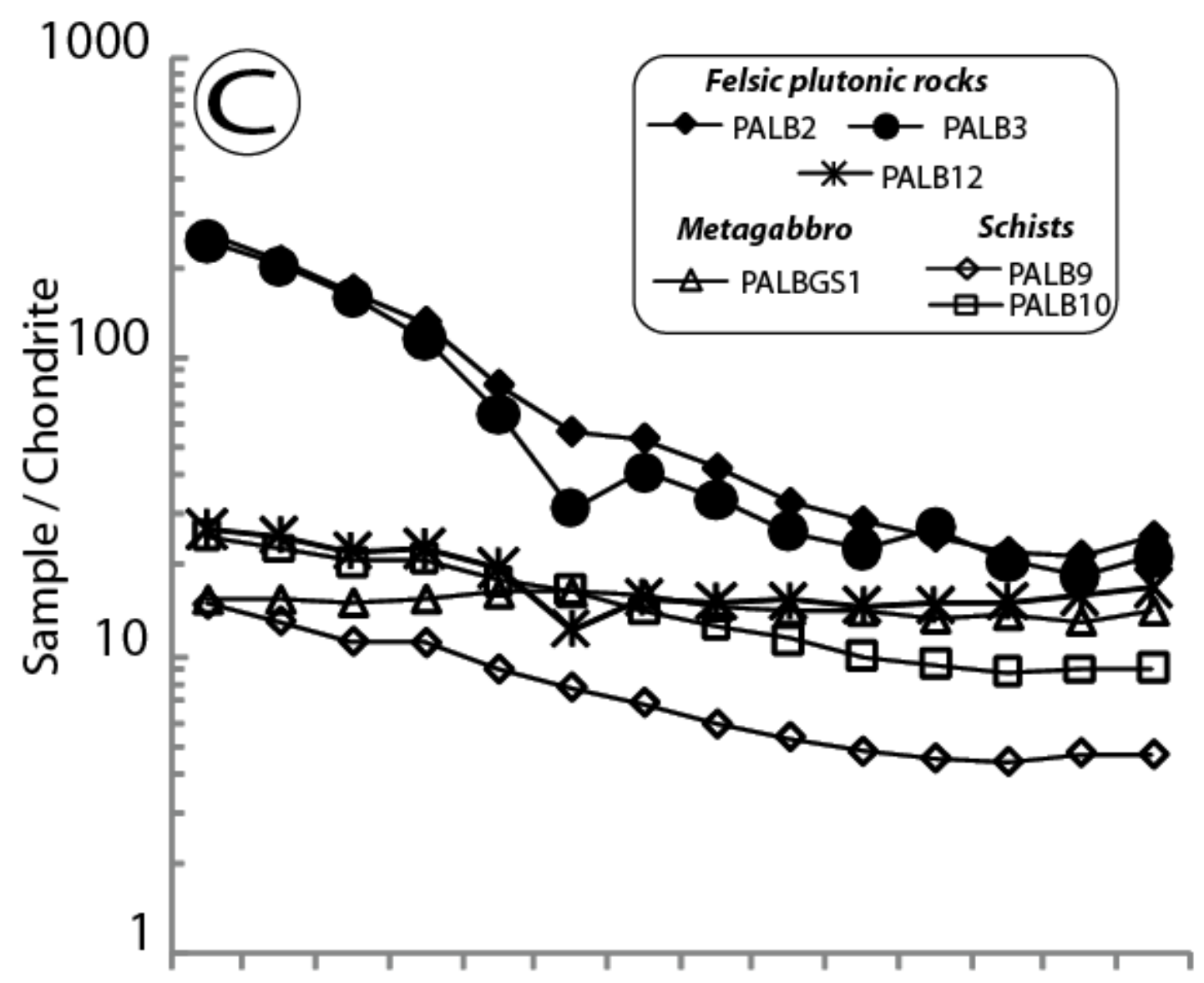

La Ce Pr Nd Sm Eu Gd Tb Dy Ho Er Tm Yb Lu

Figure 6c 


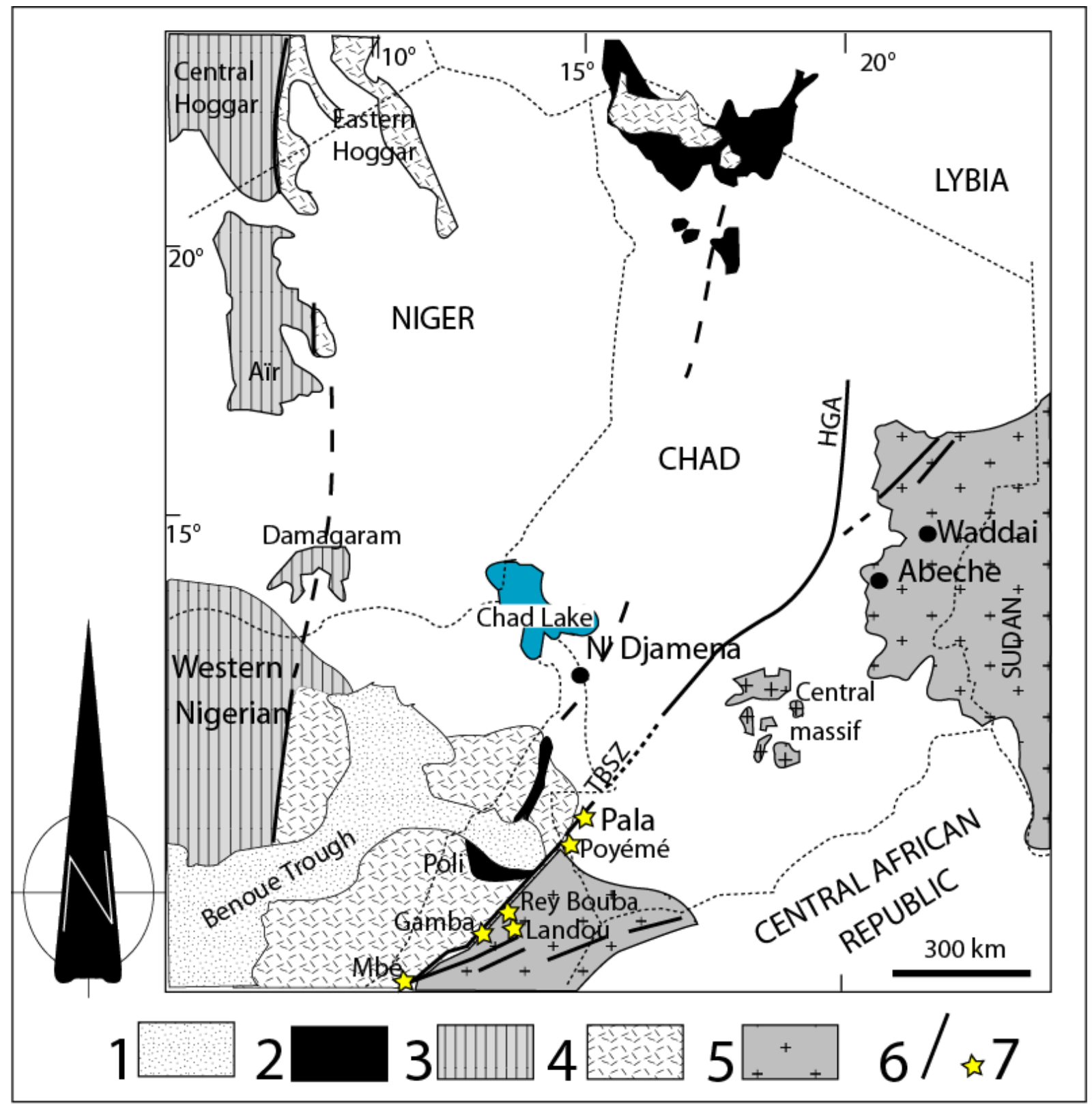

Figure 7 
Table 1: Structures of some occurrences and their gold

\begin{tabular}{|c|c|c|c|}
\hline Occurence & Localization & Enclosing rocks and structure & Content of $\mathrm{Au}$ \\
\hline $\begin{array}{l}\text { Massonébaré } \\
\text { occurrence }\end{array}$ & $\begin{array}{l}\text { Massonebaré and Gouin Lara } \\
\text { Villages, } 23 \mathrm{~km} \text { North of Pala }\end{array}$ & $\begin{array}{l}\text { Shear zones and veins of NE-SW } \\
\text { quartz in meta-andésites and. } \\
400 \mathrm{~m} \text { long and } 0,3 \text { to } 1,5 \mathrm{~m} \text { wide }\end{array}$ & $\begin{array}{l}0-33 \mathrm{~g} / \mathrm{t} \text { with } 5 \\
\mathrm{~g} / \mathrm{t} \text { in average }\end{array}$ \\
\hline \multirow{5}{*}{$\begin{array}{l}\text { Goueigoudoum } \\
\text { occurrence }\end{array}$} & $\begin{array}{l}\text { Near the Pala-Fianga road in the } \\
\text { western part of Goueigoudoum } \\
\text { village }\end{array}$ & $\begin{array}{l}\text { Veins of NE-SW quartz in meta- } \\
\text { andésites and talschistes } \\
\text { associated to NE-SW shear zone. }\end{array}$ & $1-3.5 \mathrm{~g} / \mathrm{t}^{\mathrm{a})}$ \\
\hline & Site 1 & \multirow{2}{*}{$\begin{array}{l}\text { Subhorizontal quartz veins; } 1 \text { to } \\
2 \mathrm{~m} \text { wide }\end{array}$} & $2.66 \mathrm{~g} / \mathrm{t}^{\mathrm{b})}$ \\
\hline & Site 2 & & $6.95 \mathrm{~g} / \mathrm{t}^{\mathrm{b})}$ \\
\hline & Site 3 & $\begin{array}{l}\text { Talschistes associated to NE-SW } \\
\text { shear zone }\end{array}$ & $2.53 \mathrm{~g} / \mathrm{t}^{\mathrm{b})}$ \\
\hline & Site 4 & $\begin{array}{l}\text { Mineralized lode of the south of } \\
\text { Goueigoudoum }\end{array}$ & $5 \mathrm{~kg}^{\mathrm{b})}$ \\
\hline $\begin{array}{l}\text { Mbidou } \\
\text { occurrence }\end{array}$ & $\begin{array}{l}\text { Site 1: (Pala - Fianga road) at } \\
\text { 29km of Pala, } \\
\text { Site 2: } 2 \mathrm{~km} \text { south of } \\
\text { Goueigoudoum hill }\end{array}$ & $\begin{array}{l}\text { Sericito-schists; carbonated rocks, } \\
\text { talschists and quartzites }\end{array}$ & $168 \mathrm{ppb}^{\mathrm{b})}$ \\
\hline \multirow[b]{3}{*}{$\begin{array}{l}\text { Gamboke } \\
\text { occurence }\end{array}$} & Mayo N'dala & Alluvial gold & $0-3.5 \mathrm{~g} / \mathrm{t}^{3 \mathrm{~b}) \text { and } \mathrm{c})}$ \\
\hline & South of Gamboke & $\begin{array}{l}\text { microdiorites, tufs and andesites } \\
\text { host sulfide- bearing quartz veins } \\
\text { and several shear zones oriented } \\
\text { NE-SW. The mineralization zone } \\
\text { is } 2 \mathrm{~cm} \text { to } 10 \mathrm{~m} \text { wide }\end{array}$ & $0.6-33 \mathrm{~g} / \mathrm{t}^{\mathrm{b}) \text { and }}$ ) \\
\hline & North of Gamboke & $\begin{array}{l}\text { Mineralizations in brecciated and } \\
\text { silicified zones within metagabbro } \\
\text { sills. NE-SW metavolcanic and } \\
\text { metavolcanosedimentary rocks } \\
\text { cover by laterite. These rocks } \\
\text { show strong hydrothermal } \\
\text { epidotization and silicification and } \\
\text { hosts sulfide-bearing quartz } \\
\text { stockworks. NNE-SSW to NE- } \\
\text { SW shear zone }\end{array}$ & $>1 \mathrm{~g} / \mathrm{t}$ to $5 \mathrm{~g} / \mathrm{t}^{\mathrm{b})}$ \\
\hline
\end{tabular}

a) JIPROMIT, 1995; b) Kusnir, 1991; c) Soo-Young and Jung, 2001 


\begin{tabular}{|c|c|c|c|c|c|c|c|}
\hline \multirow{2}{*}{$\begin{array}{l}\text { Rock type } \\
\text { Sample }\end{array}$} & \multicolumn{3}{|c|}{ Schists } & \multirow{2}{*}{$\frac{\text { metagabbro }}{\text { PALBGS1 }}$} & \multicolumn{3}{|c|}{ granitoids } \\
\hline & PALB9 & PAB11 & PALB10 & & PALB2 & PALB3 & PALB12 \\
\hline \multicolumn{8}{|c|}{ Major elements (Wt\%) } \\
\hline $\mathrm{SiO} 2$ & 47.78 & 45.42 & 47.81 & 52.72 & 58.63 & 62.03 & 63.13 \\
\hline $\mathrm{A} 12 \mathrm{O} 3$ & 4.91 & 2.01 & 13.44 & 14.13 & 16.05 & 16.23 & 14.5 \\
\hline $\mathrm{Fe} 2 \mathrm{O} 3 \mathrm{t}$ & 8.69 & 6.22 & 11.85 & 10.99 & 9.34 & 8.16 & 6.93 \\
\hline $\mathrm{MnO}$ & 0.19 & 0.06 & 0.17 & 0.14 & 0.11 & 0.07 & 0.15 \\
\hline $\mathrm{MgO}$ & 24.42 & 32.15 & 9.15 & 5.95 & 1.39 & 1.4 & 2.19 \\
\hline $\mathrm{CaO}$ & 7.17 & 0.64 & 11.22 & 7.99 & 4.85 & 3.36 & 3.17 \\
\hline $\mathrm{Na} 2 \mathrm{O}$ & n.d. & n.d. & 1.42 & 3.47 & 4.08 & 4.4 & 1.00 \\
\hline $\mathrm{K} 2 \mathrm{O}$ & n.d. & n.d. & 0.23 & 0.16 & 3.56 & 3.83 & 2.63 \\
\hline $\mathrm{TiO} 2$ & 0.33 & 0.01 & 1.08 & 0.99 & 1.34 & 0.91 & 0.57 \\
\hline $\mathrm{P} 2 \mathrm{O} 5$ & 0.14 & 0.03 & 0.19 & 0.19 & 0.55 & 0.28 & 0.12 \\
\hline LOI & 6.56 & 13.26 & 3.3 & 3.1 & 0.06 & 0.23 & 4.88 \\
\hline Total & 100.19 & 99.80 & 99.86 & 99.83 & 99.96 & 100.90 & 99.27 \\
\hline \multicolumn{8}{|c|}{ Trace elements (ppm) } \\
\hline As & n.d. & 5.368 & n.d. & nn.d. & 5.92 & 4.81 & 13.59 \\
\hline $\mathrm{Ba}$ & 327.4 & n.d. & 103.6 & 43.29 & 937.75 & 650.07 & 641.6 \\
\hline $\mathrm{Cd}$ & n.d. & n.d. & 0.187 & 0.121 & n.d. & n.d. & 0.147 \\
\hline $\mathrm{Ce}$ & 8.027 & n.d. & 14.03 & 9.49 & 129.23 & 124.76 & 15.56 \\
\hline Co & 74.02 & 87.61 & 47.76 & 35.61 & 16.79 & 12.64 & 9.772 \\
\hline $\mathrm{Cr}$ & 2428 & 2082 & 390.6 & 101.3 & 13.69 & 12.64 & 20.19 \\
\hline Cs & 0.247 & n.d. & 0.166 & n.d. & 2.86 & 8.2 & 1.093 \\
\hline $\mathrm{Cu}$ & 43.06 & 6.358 & 95.78 & 125.33 & 22.55 & 26.42 & n.d. \\
\hline Dy & 1.352 & 0.034 & 2.883 & 3.63 & 8.29 & 6.63 & 3.893 \\
\hline $\mathrm{Er}$ & 0.746 & 0.033 & 1.556 & 2.21 & 4.15 & 4.45 & 2.451 \\
\hline $\mathrm{Eu}$ & 0.455 & n.d. & 0.964 & 0.95 & 3.27 & 1.81 & 0.712 \\
\hline $\mathrm{Ga}$ & 6.241 & 0.746 & 17.39 & 16.71 & 29.73 & 25.57 & 17.3 \\
\hline $\mathrm{Gd}$ & 1.429 & n.d. & 2.896 & 3.31 & 11.01 & 8.46 & 3.227 \\
\hline $\mathrm{Ge}$ & 1.944 & 1.299 & 1.719 & 1.32 & 1.50 & 1.28 & 1.044 \\
\hline Hf & 0.603 & n.d. & 1.727 & 1.68 & 9.58 & 12.81 & 2.214 \\
\hline Ho & 0.269 & 0.01 & 0.567 & 0.80 & 1.60 & 1.30 & 0.832 \\
\hline $\mathrm{La}$ & 3.538 & n.d. & 5.978 & 3.67 & 60.95 & 58.43 & 6.278 \\
\hline $\mathrm{Lu}$ & 0.118 & 0.01 & 0.232 & 0.36 & 0.64 & 0.55 & 0.43 \\
\hline $\mathrm{Nb}$ & 2.106 & n.d. & 4.011 & 2.11 & 38.96 & 39.03 & 1.592 \\
\hline $\mathrm{Nd}$ & 5.172 & 0.031 & 9.852 & 7.28 & 61.56 & 54.3 & 10.7 \\
\hline $\mathrm{Ni}$ & 934 & 1563 & 132.5 & 39.84 & 10.1 & 11.95 & 19.43 \\
\hline $\mathrm{Pb}$ & 2.532 & 1.7297 & 1.4729 & 1.38 & 14.67 & 17.9 & 2.5323 \\
\hline $\operatorname{Pr}$ & 1.064 & n.d. & 1.959 & 1.44 & 16.04 & 15.23 & 2.142 \\
\hline $\mathrm{Rb}$ & 0.722 & n.d. & 4.672 & 2.69 & 99.02 & 181.66 & 54.94 \\
\hline $\mathrm{Sb}$ & 0.238 & 3.897 & 0.218 & 0.140 & 0.830 & 0.820 & n.d. \\
\hline Sm & 1.380 & n.d. & 2.732 & 2.48 & 12.40 & 9.88 & 3.029 \\
\hline $\mathrm{Sr}$ & 486.6 & 30.21 & 262.3 & 164.06 & 440.24 & 360.16 & 62.06 \\
\hline $\mathrm{Ta}$ & 0.142 & n.d. & 0.321 & 0.55 & 2.85 & 3.26 & 0.122 \\
\hline $\mathrm{Tb}$ & 0.22 & n.d. & 0.468 & 0.55 & 1.59 & 1.25 & 0.569 \\
\hline Th & 0.408 & n.d. & 0.570 & 0.38 & 9.44 & 25.07 & 0.833 \\
\hline $\mathrm{Tm}$ & 0.112 & 0.007 & 0.226 & 0.35 & 0.57 & 0.53 & 0.386 \\
\hline $\mathrm{U}$ & 0.151 & n.d. & 0.142 & 0.14 & 2.80 & 6.61 & 0.316 \\
\hline V & 87.59 & 26.86 & 295.5 & 275.61 & 59.13 & 60.92 & 90.1 \\
\hline W & 0.908 & 2.281 & n.d. & 0.38 & 1.39 & 1.65 & 0.4 \\
\hline Y & 7.608 & n.d. & 15.68 & 22.75 & 45.06 & 38.78 & 23.16 \\
\hline $\mathrm{Yb}$ & 0.800 & 0.053 & 1.539 & 2.23 & 3.7 & 3.14 & 2.717 \\
\hline $\mathrm{Zn}$ & 68.99 & 44.96 & 92.79 & 87.1 & 138.9 & 85.12 & 92.14 \\
\hline $\mathrm{Zr}$ & 20.48 & n.d. & 54.87 & 59.38 & 385.00 & 518.12 & 70.09 \\
\hline
\end{tabular}

